\title{
Do aromatase inhibitors have adverse effects on cognitive function?
}

Kelly Anne Phillips ${ }^{* 1,2}$, Karin Ribi ${ }^{3}$ and Richard Fisher ${ }^{4}$

\begin{abstract}
Aromatase inhibitors are an important component of treatment for most postmenopausal women with hormone receptor-positive, early-stage breast cancer. Women taking aromatase inhibitors experience very low levels of circulating estrogen. This might be expected to result in cognitive dysfunction given the important relationship between estrogen and cognition in the basic science literature. Several studies have examined the cognitive effects of aromatase inhibitors, including two within large randomized trials which were adequately powered to detect moderate (but not small) effects. With this caveat, the available data do not support the hypothesis that aromatase inhibitors adversely affect cognitive function or that aromatase inhibitors might have a more adverse effect on cognitive function in comparison with tamoxifen. Further research is needed for confirmation.
\end{abstract}

\section{Introduction}

Complaints of problems with memory and thinking are common in breast cancer survivors [1]. Initially, patients and researchers focused on chemotherapy as the possible cause of this cognitive dysfunction [2-7]. More recently, research has examined the potential role of adjuvant endocrine therapies.

Most postmenopausal women with early-stage breast cancer have estrogen receptor-positive disease and require at least 5 years of adjuvant endocrine therapy as part of their treatment [8]. The endocrine therapies most commonly used for postmenopausal breast cancer are tamoxifen and aromatase inhibitors, such as anastrozole, exemestane, and letrozole. Tamoxifen binds to estrogen receptors and has mixed agonist and antagonist

*Correspondence: kelly.phillips@petermac.org

'Division of Cancer Medicine, Peter MacCallum Cancer Centre, St Andrew's Place,

East Melbourne, Victoria, 3002, Australia

Full list of author information is available at the end of the article properties, depending on the target tissue [9]. Tamoxifen does not alter circulating estrogen levels in postmenopausal women. Conversely, the aromatase inhibitors reduce circulating estrogen to very low levels by inhibiting the conversion of adrenally secreted androstenedione to estradiol in adipose tissue. Large clinical trials have demonstrated that aromatase inhibitors are superior to tamoxifen in the treatment of early-stage, postmenopausal, hormone receptor-positive breast cancer [10]. It is now recommended that an aromatase inhibitor be considered for all postmenopausal women with earlystage, hormone receptor-positive breast cancer and that potential side effects be carefully considered when deciding on adjuvant endocrine therapy [10]. Some side effects of aromatase inhibitors are well characterized, but others, such as their potential effect on cognitive function, are not well understood.

\section{Preclinical data on the role of estrogen and cognitive function}

There is substantial biological evidence supporting the importance of estrogen in cognitive function [11]. Estrogen receptors are found in many areas of the brain considered important in cognition, including the hippocampus, prefrontal cortex, and amygdala [12]. Estrogen may enhance cognitive function by means of several different mechanisms (Table 1). The cholinergic and glutamate neurotransmitter systems, both important for regulation of memory and learning, are enhanced by estrogen [13-15]. Estrogen enhances neuronal plasticity $[16,17]$ and has a favorable effect on serum lipid profiles by reducing low-density lipoproteins and increasing high-density lipoproteins, which may slow progression of cerebral atherosclerosis and thus prevent cognitive decline [18]. Estrogen also modulates the expression of the apolipoprotein E gene [19], one variant of which is associated with an increased risk for Alzheimer's disease and preclinical cognitive decline [20]. However, the effect of estrogen on cognitive function is complex and may depend on underlying neurological health at the time of estrogen exposure. It has been hypothesized that if neurological processes are healthy at the time of estrogen exposure, then estrogen is beneficial, but that estrogen 


\section{Table 1. Mechanisms whereby estrogen may enhance} cognitive function

- Enhancement of cholinergic and glutamate neurotransmitter systems [13$15]$

- Enhancement of neuronal survival, differentiation, regeneration, and plasticity $[16,17]$

- Favorable effect on serum lipid profiles [18]

- Modulation of expression of apolipoprotein E [19]

Note: the relationship between estrogen and cognitive function is complex and likely non-linear.

exposure in the setting of compromised neurological health may exacerbate cognitive dysfunction [21].

It is not clear whether tamoxifen acts as an agonist or antagonist in the brain $[22,23]$. Aromatase is expressed in many regions of the brain, although little is known about its role and implications for cognitive function. The very low levels of circulating estrogen which occur with the use of aromatase inhibitors in postmenopausal women might be expected to result in a deterioration in cognitive function. Conversely, recent data suggest that letrozole administration may enhance cognition in both male and female rats $[24,25]$.

\section{Clinical studies of aromatase inhibitors and cognitive function}

Despite the widespread use of aromatase inhibitors in the treatment of breast cancer, only a handful of studies have evaluated the impact of aromatase inhibitors on cognitive function [26-33], and the results are conflicting (Table 2). Details on study design, timing of cognitive function measures, numbers of patients at baseline and last follow-up, and post hoc power are given in Table 2.

\section{Data from randomized comparisons}

The most robust data on this issue come from three studies undertaken as substudies within large randomized controlled trials $[28,29,32,33]$. One compared cognitive effects of an aromatase inhibitor with those of placebo [28]. The other two compared the cognitive function of women randomly assigned to receive tamoxifen with those randomly assigned to receive an aromatase inhibitor [29,32]. A fourth substudy, though performed within a randomized controlled trial, is considered in a subsequent section, rather than here, because the comparison performed in that substudy was not between data from randomly assigned subjects [26].

\section{IBIS II and TEAM studies}

In a substudy of the double-blind International Breast Intervention Study II (IBIS II) [28], the cognitive function of postmenopausal women who had an increased risk for breast cancer and who were randomly assigned to anastrozole was compared with that of those randomly assigned to placebo. Cognitive function was assessed prior to random assignment $(\mathrm{n}=227)$, at 6 months $(\mathrm{n}=207$, $91 \%)$, and at 2 years $(\mathrm{n}=151,67 \%)$. The functional areas of verbal and visual memory, working memory, processing speed, and executive function were assessed. There was no significant difference between the anastrozole and placebo groups on any cognitive tasks at any of the time points. Post hoc power calculations (results presented in Table 2) show that each comparison in this study had reasonable power to detect a moderate difference in cognitive function between those treated with anastrozole versus placebo.

The open-label Tamoxifen and Exemestane Adjuvant Multinational (TEAM) study randomly assigned postmenopausal women with early-stage breast cancer to receive adjuvant exemestane for 5 years or tamoxifen for 2.5 to 3 years followed by exemestane for 2 to 2.5 years [29]. The cognitive domains of verbal memory, visual memory, processing speed, executive function, manual motor speed, verbal fluency, and reaction speed were assessed prior to commencement of adjuvant endocrine therapy and after 1 year on therapy in a subgroup of 179 women (and a non-randomly assigned group of 120 untreated healthy controls who were similarly aged friends or relatives of trial participants). The cognitive function of those randomly assigned to exemestane was compared with that of those randomly assigned to tamoxifen. Tamoxifen-treated patients had slower information-processing speed in comparison with those treated with exemestane. This study had adequate power to detect moderate-sized effects on cognitive function (Table 2). Cognitive function was also compared between non-randomly assigned groups (that is, those randomly assigned to tamoxifen and healthy controls and those randomly assigned to exemestane and healthy controls). Those results are discussed in the relevant section of 'Data from non-randomized comparisons' below.

The IBIS II and TEAM studies provide good evidence that there is no moderate or large adverse effect of aromatase inhibitors on cognitive function when compared with placebo or tamoxifen. However, smaller effects on cognitive function cannot be excluded. Confirmatory controlled studies would provide additional reassurance but are unlikely. It is also important to note that the data from these two studies do not provide information about the cognitive effects of more than 2 years of aromatase inhibitor therapy. In neither the IBIS II nor the TEAM study did the patients receive chemotherapy, so the results are not confounded by potential cognitive alterations induced by prior chemotherapy.

\section{BIG 1-98}

The double-blind Breast International Group 1-98 (BIG 1-98) study randomly assigned postmenopausal 
Table 2. Clinical studies of aromatase inhibitors and cognitive function

\begin{tabular}{|c|c|c|c|c|c|c|c|c|}
\hline \multirow[b]{2}{*}{ Study } & \multirow[b]{2}{*}{$\begin{array}{l}\text { Study } \\
\text { design }\end{array}$} & \multirow[b]{2}{*}{$\begin{array}{l}\text { Timing of } \\
\text { measures }\end{array}$} & \multirow{2}{*}{$\begin{array}{l}\text { Number } \\
\text { at } \\
\text { baseline }\end{array}$} & \multirow{2}{*}{$\begin{array}{l}\text { Number } \\
\text { at last } \\
\text { follow-up }\end{array}$} & \multirow[b]{2}{*}{$\begin{array}{l}\text { Treatment } \\
\text { comparison }\end{array}$} & \multicolumn{2}{|c|}{ Power $^{\mathrm{a}}$} & \multirow[b]{2}{*}{ Conclusions } \\
\hline & & & & & & $\mathrm{ES}=0.50$ & $E S=0.35$ & \\
\hline \multirow[t]{2}{*}{ |BIS || [28] } & \multirow[t]{2}{*}{ RCT } & \multirow{2}{*}{$\begin{array}{l}\text { Pre-Rx, at } 6 \\
\text { months on } \mathrm{Rx} \text {, } \\
\text { and at } 2 \text { years } \\
\text { on } \mathrm{Rx}\end{array}$} & \multirow[t]{2}{*}{227} & \multirow[t]{2}{*}{151} & Anastrozole & \multirow{2}{*}{$\begin{array}{l}\text { 94\% (6-month } \\
\text { analysis), } \\
\text { 87\% (2-year } \\
\text { analysis) }\end{array}$} & \multirow{2}{*}{$\begin{array}{l}\text { 71\% (6-month } \\
\text { analysis), } \\
\text { 58\% (2-year } \\
\text { analysis) }\end{array}$} & \multirow{2}{*}{$\begin{array}{l}\text { No statistically significant } \\
\text { difference in cognitive } \\
\text { function between arms was } \\
\text { observed. }\end{array}$} \\
\hline & & & & & Placebo & & & \\
\hline \multirow[t]{2}{*}{ TEAM [29] } & \multirow{2}{*}{$\begin{array}{l}\text { RCT and } \\
\text { control } \\
\text { group }\end{array}$} & \multirow{2}{*}{$\begin{array}{l}\text { Pre-Rx and at } 1 \\
\text { year on } R x\end{array}$} & \multirow{2}{*}{$\begin{array}{c}179 \\
+120 \\
\text { healthy } \\
\text { controls }\end{array}$} & \multirow{2}{*}{$\begin{array}{r}179 \\
+120\end{array}$} & Exemestane & \multirow[b]{2}{*}{$\begin{array}{c}\text { 93\% (tamoxifen } \\
\text { compared with } \\
\text { exemestane), } \\
93 \% \text { (tamoxifen } \\
\text { compared with } \\
\text { control), } \\
96 \% \text { (exemestane } \\
\text { compared with } \\
\text { control) }\end{array}$} & \multirow[b]{2}{*}{$\begin{array}{c}67 \% \text { (tamoxifen } \\
\text { compared with } \\
\text { exemestane), } \\
68 / \% \text { (tamoxifen } \\
\text { compared with } \\
\text { control), } \\
\text { 73\% (exemestane } \\
\text { compared with } \\
\text { control) }\end{array}$} & \multirow[b]{2}{*}{$\begin{array}{l}\text { No statistically significant } \\
\text { effect of exemestane on } \\
\text { cognition was observed; } \\
\text { tamoxifen was associated } \\
\text { with worse verbal memory, } \\
\text { executive function, and } \\
\text { information-processing speed. }\end{array}$} \\
\hline & & & & & $\begin{array}{l}\text { Tamoxifen }(\rightarrow \\
\text { exemestane) }\end{array}$ & & & \\
\hline \multirow[t]{2}{*}{$\begin{array}{l}\text { BIG 1-98 } \\
{[32,33]}\end{array}$} & \multirow[t]{2}{*}{ RCT } & \multirow[t]{2}{*}{$\begin{array}{l}\text { At } 5 \text { years on } \\
\text { Rx and } 1 \text { year } \\
\text { after ceasing } R x\end{array}$} & \multirow[t]{2}{*}{120} & \multirow[t]{2}{*}{100} & $\begin{array}{l}\text { Tamoxifen or } \\
\text { letrozole } \rightarrow \\
\text { tamoxifen }\end{array}$ & \multirow[t]{2}{*}{$78 \%$} & \multirow[t]{2}{*}{$48 \%$} & \multirow{2}{*}{$\begin{array}{l}\text { Overall cognitive function was } \\
\text { significantly better in patients } \\
\text { taking letrozole rather than } \\
\text { tamoxifen at year } 5 \text {. } \\
\text { Significant improvement in } \\
\text { cognition after completion } \\
\text { of endocrine therapy was } \\
\text { observed. }\end{array}$} \\
\hline & & & & & $\begin{array}{l}\text { Letrozole or } \\
\text { tamoxifen } \rightarrow \\
\text { letrozole }\end{array}$ & & & \\
\hline \multirow[t]{2}{*}{ ATAC [26] } & \multirow[t]{2}{*}{$\begin{array}{c}\text { Cross- } \\
\text { sectional }\end{array}$} & \multirow[t]{2}{*}{$\begin{array}{l}\text { At } 1 \text { to } 5 \text { years } \\
\text { on } R x \text { (mean of } \\
3 \text { years) }\end{array}$} & \multirow[t]{2}{*}{ 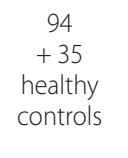 } & \multirow[t]{2}{*}{ N/A } & $\begin{array}{l}\text { Anastrozole } \\
\text { or tamoxifen } \\
\text { (combined) }\end{array}$ & $71 \%$ & $42 \%$ & $\begin{array}{l}\text { Endocrine therapy users had } \\
\text { worse verbal memory and } \\
\text { processing speed compared }\end{array}$ \\
\hline & & & & & Untreated & & & \\
\hline Bender, et & & At $\geq 3$ months & 31 & N/A & Anastrozole & $28 \%$ & $16 \%$ & Poorer verbal and visual \\
\hline & $\begin{array}{l}\text { non- } \\
\text { randomized }\end{array}$ & & & & Tamoxifen & & & $\begin{array}{l}\text { learning in patients taking } \\
\text { anastrozole compared with } \\
\text { patients taking tamoxifen was } \\
\text { observed. }\end{array}$ \\
\hline Collins, et & Non- & Around start of & 45 & 'Attrition & Anastrozole & 48\% (tamoxifen), & 27\% (tamoxifen), & No significant difference \\
\hline & & months on $\mathrm{Rx}$ & $\begin{array}{l}\text { healthy } \\
\text { controls }\end{array}$ & all groups' & Tamoxifen & e) & ole) & $\begin{array}{l}\text { Detween treatments, relative } \\
\text { to healthy controls, was } \\
\text { observed. }\end{array}$ \\
\hline $\begin{array}{l}\text { Hermelink, } \\
\text { et al. [30] }\end{array}$ & $\begin{array}{l}\text { Non- } \\
\text { randomized }\end{array}$ & $\begin{array}{l}\text { Before start of } \\
\mathrm{CT} \text {, before final }\end{array}$ & 101 & 92 & $\begin{array}{l}\text { Anastrozole or } \\
\text { letrozole }\end{array}$ & $61 \%$ & $35 \%$ & $\begin{array}{l}\text { No statistically significant } \\
\text { difference between tamoxifen }\end{array}$ \\
\hline & & $\begin{array}{l}\text { cycle of }(1, \text { and } \\
\text { at } 1 \text { year (after } \\
\text { baseline) }\end{array}$ & & & Tamoxifen & & & $\begin{array}{l}\text { and aromatase inhibitor on } \\
\text { any cognitive domain was } \\
\text { observed. }\end{array}$ \\
\hline
\end{tabular}

aThe power calculations are for comparing two groups, with the numbers of patients as given in each paper, for effect sizes (ESs) of both 0.50 (medium) and 0.35 (small to medium). Two-sided tests at the alpha $=0.05$ level are assumed. The calculations are necessarily indicative only and do not closely incorporate all the design features of the studies which might affect power (including data quality and completeness) or adjust for multiple comparisons. ATAC, Anastrozole, Tamoxifen Alone or Combined; BIG 1-98, Breast International Group 1-98; CT, chemotherapy; IBIS II, International Breast Intervention Study II; N/A, not applicable; RCT, randomized controlled trial; Rx, endocrine treatment; TEAM, Tamoxifen and Exemestane Adjuvant Multinational.

women with hormone receptor-positive tumors to receive one of the following adjuvant endocrine therapy options: (a) tamoxifen for 5 years, (b) letrozole for 5 years, (c) tamoxifen for 2 years followed by letrozole for 3 years, or (d) letrozole for 2 years followed by tamoxifen for 3 years. Patients were stratified according to whether or not they had received prior chemotherapy. In a small subset of 120 patients, a cognitive function substudy examined the differences in cognitive function associated with each endocrine treatment [32]. A brief computerized battery of tests measuring psychomotor speed, visual attention, working memory, visual learning and memory, and verbal learning and memory (CogState Ltd., Melbourne, Australia) [34] was administered after approximately 5 years on therapy and again approximately 1 year after ceasing therapy. During the fifth year on adjuvant 
endocrine therapy, patients taking letrozole (arms B and C) had better overall cognitive function in comparison with those taking tamoxifen (arms A and D). The analysis comparing the monotherapy arms in this study was underpowered and showed no statistically significant difference between the cognitive function of women who had taken tamoxifen for 5 years and those who had take letrozole for 5 years.

A novel aspect of the BIG 1-98 cognitive function substudy was that it also assessed cognition approximately 1 year after patients had completed their adjuvant endocrine therapy [33]. The substudy showed significant improvement in cognition after cessation of therapy. The finding was consistent across all cognitive tasks and consistent in women taking either tamoxifen or letrozole at the 5-year time point. The observed effect size was moderate for the change in overall cognition. In this study, cognitive function was not assessed prior to the start of endocrine therapy, so it is not clear how cognition 1 year after cessation of therapy might have compared with baseline cognitive function prior to commencement of adjuvant endocrine therapy. Nevertheless, this study suggests that any effect that adjuvant endocrine therapy might have on cognition in postmenopausal women is at least partly reversible with cessation of endocrine therapy.

\section{Data from non-randomized comparisons ATAC}

In a pilot substudy of the randomized trial of Anastrozole, Tamoxifen Alone or Combined (ATAC) [26], the cognitive function of 94 breast cancer patients taking adjuvant tamoxifen or anastrozole (analyzed together) was compared with that of a convenience sample of 35 healthy untreated controls. None of the patients had had prior chemotherapy. Standard neuropsychological tests, which consisted of measures of processing speed, working memory, attention, visual memory, and verbal memory, were used. Women were tested after 12 to 60 months of adjuvant endocrine therapy (mean of 36 months). Those receiving adjuvant endocrine therapy performed less well on tests of verbal memory and processing speed compared with untreated controls. A comparison of the cognitive function of women taking anastrozole with that of women taking tamoxifen was not performed as the sample size was considered too small; thus, this study does not provide specific information on the impact of aromatase inhibitors on cognitive function.

\section{TEAM}

The TEAM study has been described above [29]. In addition to conducting a comparison between the randomly assigned groups in this study, the authors compared the cognitive function of healthy controls with that of those randomly assigned to tamoxifen or exemestane. After 1 year of use, exemestane was not statistically significantly associated with lower cognitive function in comparison with healthy controls, whereas 1 year of tamoxifen treatment was associated with worse performance in terms of verbal memory and executive function. The observed effect sizes were moderate for all affected cognitive domains.

Three other non-randomized studies have examined the influence on cognitive function of tamoxifen compared with aromatase inhibitors [27,30,31]. Two studies found no statistically significant difference in overall cognitive function between patients taking tamoxifen versus aromatase inhibitors [30,31], but these studies were small and underpowered (Table 2). The third, a cross-sectional study of a small convenience sample of 31 postmenopausal women, suggested that learning and memory were worse in breast cancer patients treated for at least 3 months with anastrozole $(\mathrm{n}=15)$ compared with tamoxifen $(\mathrm{n}=16)$ [27]. However, the women who received tamoxifen in that study had been taking the endocrine therapy for significantly longer (mean of 23.8 months versus 14.3 months) and were significantly younger (mean of 48.2 years versus 57.4 years) than those who received anastrozole, and this may have confounded the results. Also, the cross-sectional design, with no pretreatment measures, makes it impossible to determine whether the results represent a change from pretreatment performance.

\section{Interpretation and future research directions}

To date, the hypothesis that aromatase inhibitors might have an adverse impact on cognitive function and might be worse than tamoxifen in that regard (because of lower circulating estrogen levels during treatment with aromatase inhibitors) has not been confirmed by the available data. However, there are a number of limitations of the existing studies and further robustly designed research is required.

\section{Limitations of existing studies}

Four of the studies reviewed used a convenience/observational sample design $[26,27,30,31]$. This is a weakness because any observed association between cognitive function and type of endocrine therapy used is not necessarily causal, because of the possibility of underlying confounding. Substudies within randomized controlled trials are a potentially more valid approach because they are less susceptible to bias.

All studies had relatively small sample sizes and thus limited power to detect small effects on cognitive function, although two $[28,29]$ were adequately powered to detect moderate effects (Table 2). The nature of studies looking for evidence of cognitive impairment is such that 
multiple endpoints, representing the multiple ways in which cognitive impairment may be expressed (cognitive domains), need to be examined. This implies that studies need to be designed and their results interpreted appropriately in order to avoid excessive risk of falsepositive errors. This usually requires that a priori summary measures be employed (as in the BIG 1-98 study) or that analytic methods, such as those of Hochberg, Holm, or Bonferroni, be used. Such requirements may have implications for sample size in these studies.

Only one of the published studies provides data on the effect of aromatase inhibitors on cognition over the longer term [32,33]. This is an important point given that most women receive at least 5 years of adjuvant endocrine therapy.

\section{Future research}

It is disappointing that, despite random assignment of tens of thousands of women in adjuvant and preventive endocrine therapy trials, there are still inadequate data regarding the cognitive effects of aromatase inhibitors. Consideration should be given to incorporating measures of cognitive function into the main protocol of future studies in the same way that quality-of-life measures often are. This would avoid the need for separate substudies, recruitment to which can be hampered by the need for separate funding, protocols, and ethics approval. Of course, assessing cognitive function in multiinstitutional, often multi-national, studies is potentially challenging. The use of relatively brief, validated computerized tools, such as that used in the BIG 1-98 study (CogState Ltd.) [34], rather than lengthy 'paper and pencil' standard neuropsychological tests, should make this more feasible. Future research might also employ translational approaches using functional brain imaging or may include study designs other than clinical trials (such as population-based studies using SEER [Surveillance, Epidemiology and End Results] data linked to Medicare claims, although such designs also have limitations [35]) or both. Studies of cognitive function in larger samples of patients would enable important subgroup analyses, driven by biological hypotheses, to be undertaken.

The role of estrogen in cognitive function is clearly important but complex. The relationship between amount of circulating estrogen and cognitive function may not be linear. It has been suggested that estrogen may have either protective or harmful effects on the brain depending on age, type of menopause (natural versus surgical), or stage of menopause [36]. Several studies have suggested that surgical oophorectomy in premenopausal women adversely impacts cognitive function, particularly verbal memory, and that the effect can be ameliorated by the use of hormone replacement therapy
[37-39]. A recent study suggested that premenopausal oophorectomy is a risk factor for cognitive impairment and dementia later in life [40]. However, adverse effects of estrogen on cognitive function have also been suggested. In the Women's Health Initiative Study, which randomly assigned postmenopausal women to estrogen replacement therapy or placebo, estrogen increased the risk of dementia in women older than 65 years $[41,42]$. This suggests that, while estrogens may be protective of cognition around the time of menopause, they may have detrimental effects on older women. The question of whether aromatase inhibitors have a more adverse effect on the cognitive function of younger postmenopausal women, who may not have already adapted to relative hypo-estrogenism, in comparison with older postmenopausal women requires further research. This will be especially important if ovarian ablation combined with aromatase inhibitors becomes a standard of care for premenopausal women with early-stage breast cancer [43]. Similarly, it would be of interest to know whether women who use estrogen replacement therapy prior to their breast cancer diagnosis might be more likely than those who do not to develop cognitive dysfunction when taking aromatase inhibitors.

Overweight women generally have more aromatase enzyme availability. In a study of premenopausal patients treated with a gonadotropin-releasing hormone (GnRH) agonist and anastrozole, those who were overweight had worse disease-free survival compared with patients of normal weight [44]. It has been hypothesized (but not proven) that, in overweight women, the standard dose of aromatase inhibitor may not be sufficient to adequately lower estrogen levels. Thus, it would be of interest to examine whether aromatase inhibitors might have different effects on cognitive dysfunction in overweight and obese women compared with women of normal weight. Another question of considerable interest is whether women who get worse menopausal side effects, such as hot flushes, from aromatase inhibitors might be more likely to develop cognitive problems.

Whether different aromatase inhibitors might have different effects on cognition is an important question but is currently unanswered on the basis of the available data. In contrast to the non-steroidal aromatase inhibitors anastrozole and letrozole, the steroidal aromatase inhibitor exemestane has androgenic properties that might confer an advantage for cognitive functioning $[45,46]$. Future research differentiating any possible cognitive effect of the different available aromatase inhibitors would be of considerable interest.

Most studies to date have not demonstrated a significant association between objective cognitive impairment and patients' self-report of their cognitive function, but several studies have found significant correlations 
This article is part of a review series on Controversies in Al therapy, edited by Lewis Chodosh. Other articles in the series can be found online at http://breast-cancer-research.com/series/Al_controversies.

between self-reported cognitive function and depression and/or anxiety $[26,28,47,48]$. Thus, subjective cognitive complaints may be an indicator of an underlying mood disorder. Patients who report memory problems while taking aromatase inhibitors should be evaluated for a potential mood disorder, as these can be effectively treated.

\section{Conclusions}

During discussions of cognitive dysfunction as a possible side effect of adjuvant endocrine therapy, women should be told of the limitations of the current evidence in this area. However, with that caveat, it is reasonable to tell postmenopausal women that there is currently no clear evidence that use of an aromatase inhibitor to treat their breast cancer will result in a deterioration in their cognitive function. They can also be informed that, given the available evidence, the effect of an aromatase inhibitor on cognitive function does not appear to be worse than that of the alternative agent, tamoxifen.

\section{Abbreviations}

BIG 1-98, Breast International Group 1-98; IBIS II, International Breast Intervention Study II;TEAM, Tamoxifen and Exemestane Adjuvant Multinational.

\section{Competing interests}

The authors declare that they have no competing interests.

\section{Acknowledgments}

KAP is supported by the John Colebatch Clinical Research Fellowship of Cancer Council Victoria. The authors thank Jürg Bernhard for his insightful review of an earlier version of this manuscript.

\section{Author details}

'Division of Cancer Medicine, Peter MacCallum Cancer Centre, St Andrew's Place, East Melbourne, Victoria, 3002, Australia; 2Department of Medicine, St Vincent's Hospital, The University of Melbourne, Victoria Parade, Fitzroy, Victoria, 3065, Australia; ${ }^{3}$ BCSG Coordinating Centre, Effingerstrasse 40, 8003, Bern, Switzerland: ${ }^{4}$ Centre for Biostatistics and Clinical Trials, Peter MacCallum Cancer Centre, St Andrew's Place, East Melbourne, Victoria, 3002, Australia.

Published: 23 February 2011

\section{References}

1. Shilling $V$, Jenkins $V$ : Self-reported cognitive problems in women receiving adjuvant therapy for breast cancer. Eur J Oncol Nurs 2007, 11:6-15.

2. Schagen SB, Muller MJ, Boogerd W, Mellenbergh GJ, van Dam FS: Change in cognitive function after chemotherapy: a prospective longitudinal study in breast cancer patients. J Natl Cancer Inst 2006, 98:1742-1745.

3. Vardy J, Rourke S, Tannock IF: Evaluation of cognitive function associated with chemotherapy: a review of published studies and recommendations for future research. J Clin Oncol 2007, 25:2455-2463.

4. Hermelink K, Untch M, Lux MP, Kreienberg R, BeckT, Bauerfeind I, Munzel K: Cognitive function during neoadjuvant chemotherapy for breast cancer: results of a prospective, multicenter, longitudinal study. Cancer 2007 109:1905-1913.

5. Jansen CE, Dodd MJ, Miaskowski CA, Dowling GA, Kramer J: Preliminary results of a longitudinal study of changes in cognitive function in breast cancer patients undergoing chemotherapy with doxorubicin and cyclophosphamide. Psychooncology 2008, 17:1189-1195.

6. Kreukels BP, van Dam FS, Ridderinkhof KR, Boogerd W, Schagen SB: Persistent neurocognitive problems after adjuvant chemotherapy for breast cancer. Clin Breast Cancer 2008, 8:80-87.

7. Vardy J: Cognitive function in breast cancer survivors. Cancer Treat Res 2009 151:387-419.

8. Tamoxifen for early breast cancer: an overview of the randomised trials. Early Breast Cancer Trialists' Collaborative Group. Lancet 1998, 351:1451-1467.

9. Riggs BL, Hartmann LC: Selective estrogen-receptor modulators mechanisms of action and application to clinical practice. N Engl J Med 2003, 348:618-629.

10. Burstein HJ, Prestrud AA, Seidenfeld J, Anderson H, Buchholz TA, Davidson NE, Gelmon KE, Giordano SH, Hudis CA, Malin J, Mamounas EP, Rowden D, Solky AJ, Sowers MR, Stearns V, Winer EP, Somerfield MR, Griggs JJ; American Society of Clinical Oncology: American Society of Clinical Oncology clinical practice guideline: update on adjuvant endocrine therapy for women with hormone receptor-positive breast cancer. J Clin Oncol 2010, 28:3784-3796.

11. Sherwin BB: Estrogen and cognitive functioning in women. Endocr Rev 2003, 24:133-151.

12. Ciocca DR, Roig LM: Estrogen receptors in human nontarget tissues: biological and clinical implications. Endocr Rev 1995, 16:35-62.

13. Gazzaley AH, Weiland NG, McEwen BS, Morrison JH: Differential regulation of NMDAR1 mRNA and protein by estradiol in the rat hippocampus. J Neurosci 1996, 16:6830-6838.

14. Luine VN: Estradiol increases choline acetyltransferase activity in specific basal forebrain nuclei and projection areas of female rats. Exp Neurol 1985, 89:484-490.

15. O'Malley CA, Hautamaki RD, Kelley M, Meyer EM: Effects of ovariectomy and estradiol benzoate on high affinity choline uptake, ACh synthesis, and release from rat cerebral cortical synaptosomes. Brain Res 1987, 403:389-392.

16. Matsumoto A: Synaptogenic action of sex steroids in developing and adult neuroendocrine brain. Psychoneuroendocrinology 1991, 16:25-40.

17. McEwen BS, Woolley CS: Estradiol and progesterone regulate neuronal structure and synaptic connectivity in adult as well as developing brain. Exp Gerontol 1994, 29:431-436.

18. Applebaum-Bowden D, McLean P, Steinmetz A, Fontana D, Matthys C, Warnick GR, Cheung M, Albers JJ, Hazzard WR: Lipoprotein, apolipoprotein, and lipolytic enzyme changes following estrogen administration in postmenopausal women. J Lipid Res 1989, 30:1895-1906.

19. Srivastava RA, Bhasin N, Srivastava N: Apolipoprotein E gene expression in various tissues of mouse and regulation by estrogen. Biochem Mol Biol Int 1996, 38:91-101.

20. Yaffe K, Cauley J, Sands L, Browner W: Apolipoprotein E phenotype and cognitive decline in a prospective study of elderly community women. Arch Neurol 1997, 54:1110-1114.

21. Chen S, Nilsen J, Brinton RD: Dose and temporal pattern of estrogen exposure determines neuroprotective outcome in hippocampal neurons: therapeutic implications. Endocrinology 2006, 147:5303-5313.

22. Sumner BE, Grant KE, Rosie R, Hegele-Hartung C, Fritzemeier KH, Fink G: Effects of tamoxifen on serotonin transporter and 5-hydroxytryptamine( $2 \mathrm{~A}$ ) receptor binding sites and mRNA levels in the brain of ovariectomized rats with or without acute estradiol replacement. Brain Res Mol Brain Res 1999, 73:119-128.

23. Jenkins $V$, Atkins $L$, Fallowfield L: Does endocrine therapy for the treatment and prevention of breast cancer affect memory and cognition? Eur J Cancer 2007, 43:1342-1347.

24. Alejandre-Gomez M, Garcia-Segura LM, Gonzalez-Burgos I: Administration of an inhibitor of estrogen biosynthesis facilitates working memory acquisition in male rats. Neurosci Res 2007, 58:272-277.

25. Aydin M, Yilmaz B, Alcin E, Nedzvetsky VS, Sahin Z, Tuzcu M: Effects of letrozole on hippocampal and cortical catecholaminergic neurotransmitter levels, neural cell adhesion molecule expression and spatial learning and memory in female rats. Neuroscience 2008, 151:186-194.

26. Jenkins V, Shilling V, Fallowfield L, Howell A, Hutton S: Does hormone therapy for the treatment of breast cancer have a detrimental effect on 
memory and cognition? A pilot study. Psychooncology 2004, 13:61-66.

27. Bender CM, Sereika SM, Brufsky AM, Ryan CM, Vogel VG, Rastogi P, Cohen SM, Casillo FE, Berga SL: Memory impairments with adjuvant anastrozole versus tamoxifen in women with early-stage breast cancer. Menopause 2007, 14:995-998

28. Jenkins VA, Ambroisine LM, Atkins L, Cuzick J, Howell A, Fallowfield L: Effects of anastrozole on cognitive performance in postmenopausal women: a randomised, double-blind chemoprevention trial (IBIS II). Lancet Oncol 2008, 9:953-961.

29. Schilder CM, Seynaeve C, Beex LV, Boogerd W, Linn SC, Gundy CM, Huizenga HM, Nortier JW, van de Velde CJ, van Dam FS, Schagen SB: Effects of tamoxifen and exemestane on cognitive functioning of postmenopausal patients with breast cancer: results from the neuropsychological side study of the tamoxifen and exemestane adjuvant multinational trial. J Clin Oncol 2010, 28:1294-1300.

30. Hermelink K, Henschel V, Untch M, Bauerfeind I, Lux MP, Munzel K: Shortterm effects of treatment-induced hormonal changes on cognitive function in breast cancer patients: results of a multicenter, prospective, longitudinal study. Cancer 2008, 113:2431-2439.

31. Collins B, Mackenzie J, Stewart A, Bielajew C, Verma S: Cognitive effects of hormonal therapy in early stage breast cancer patients: a prospective study. Psychooncology 2009, 18:811-821.

32. Phillips KA, Ribi K, Sun Z, Stephens A, Thompson A, Harvey V, Thürlimann B, Cardoso F, Pagani O, Coates AS, Goldhirsch A, Price KN, Gelber RD, Bernhard J: Cognitive function in postmenopausal women receiving adjuvant letrozole or tamoxifen for breast cancer in the BIG 1-98 randomized trial. Breast (Edinburgh, Scotland) 2010, 19:388-395.

33. Phillips KA, Aldridge J, Ribi K, Sun Z, Thompson A, Harvey V, Thürlimann B, Cardoso F, Pagani O, Coates AS, Goldhirsch A, Price KN, Gelber RD, Bernhard J: Cognitive function in postmenopausal breast cancer patients one year after completing adjuvant endocrine therapy with letrozole and/or tamoxifen in the BIG 1-98 trial. Breast Cancer Res Treat 2011, 126:221-226.

34. CogState homepage [www.cogstate.com]

35. Baxter NN, Durham SB, Phillips KA, Habermann E, Virning BA. Risk of dementia in older breast cancer survivors: a population-based cohort study of the association with adjuvant chemotherapy. J Am Geriatr SoC 2009, 57:403-411.

36. Rocca WA, Grossardt BR, Shuster LT: Oophorectomy, menopause, estrogen, and cognitive aging: the timing hypothesis. Neurodegener Dis 2010, 7:163-166.

37. Farrag AK, Khedr EM, Abdel-Aleem H, Rageh TA: Effect of surgical menopause on cognitive functions. Dement Geriatr Cogn Disord 2002, 13:193-198.

38. Phillips SM, Sherwin BB: Effects of estrogen on memory function in surgically menopausal women. Psychoneuroendocrinology 1992, 17:485-495.

39. Sherwin BB: Estrogen and/or androgen replacement therapy and cognitive functioning in surgically menopausal women. Psychoneuroendocrinology 1988, 13:345-357.

40. Rocca WA, Bower JH, Maraganore DM, Ahlskog JE, Grossardt BR, de Andrade $M$, Melton $L J$ 3rd: Increased risk of cognitive impairment or dementia in women who underwent oophorectomy before menopause. Neurology 2007, 69:1074-1083.

41. Anderson GL, Limacher M, Assaf AR, Bassford T, Beresford SA, Black H, Bonds D, Brunner R, Brzyski R, Caan B, Chlebowski R, Curb D, Gass M, Hays J, Heiss G, Hendrix S, Howard BV, Hsia J, Hubbell A, Jackson R, Johnson KC, Judd H, Kotchen JM, Kuller L, LaCroix AZ, Lane D, Langer RD, Lasser N, Lewis CE, Manson J, et al:: Effects of conjugated equine estrogen in postmenopausal women with hysterectomy: the Women's Health Initiative randomized controlled trial. JAMA 2004, 291:1701-1712.

42. Shumaker SA, Legault C, Kuller L, Rapp SR, Thal L, Lane DS, Fillit H, Stefanick ML, Hendrix SL, Lewis CE, Masaki K, Coker LH; Women's Health Initiative Memory Study: Conjugated equine estrogens and incidence of probable dementia and mild cognitive impairment in postmenopausal women: Women's Health Initiative Memory Study. JAMA 2004, 291:2947-2958.

43. Price KN, Goldhirsch A: Clinical trial update: International Breast Cancer Study Group. Breast Cancer Res 2005, 7:252-254.

44. Pfeiler G, Königsberg R, Singer CF, Seifert M, Dubsky PC, Samonigg H, Bjelic Radisic V, Greil R, Marth C, Gnant M: Impact of body mass index (BMI) on endocrine therapy in premenopausal breast cancer patients: an analysis of the ABCSG-12 trial [abstract 512]. J Clin Oncol 2010, 28 (suppl 15):71S.

45. Ariazi EA, Leitão A, Oprea TI, Chen B, Louis T, Bertucci AM, Sharma CG, Gill SD, Kim HR, Shupp HA, Pyle JR, Madrack A, Donato AL, Cheng D, Paige JR, Jordan VC: Exemestane's 17-hydroxylated metabolite exerts biological effects as an androgen. Mol Cancer Ther 2007, 6:2817-2827.

46. Hirshman E, Merritt P, Wang CC, Wierman M, Budescu DV, Kohrt W, Templin JL, Bhasin S: Evidence that androgenic and estrogenic metabolites contribute to the effects of dehydroepiandrosterone on cognition in postmenopausal women. Horm Behav 2004, 45:144-155.

47. Schilder CM, Eggens PC, Seynaeve C, Linn SC, Boogerd W, Gundy CM, Beex LV, Van Dam FS, Schagen SB: Neuropsychological functioning in postmenopausal breast cancer patients treated with tamoxifen or exemestane after AC-chemotherapy: cross-sectional findings from the neuropsychological TEAM-side study. Acta Oncol 2008, 48:76-85.

48. Pullens MJ, De Vries J, Roukema JA: Subjective cognitive dysfunction in breast cancer patients: a systematic review. Psychooncology 2010, 19:1127-1138.

doi:10.1186/bcr2806

Cite this article as: Phillips KA, et al.: Do aromatase inhibitors have adverse effects on cognitive function? Breast Cancer Research 2011, 13:203. 